awarded to winners in all age groups. Golf: the Golf Tournament will be held at two locations, Corpus Christi Country Club and Padre Island Country Club. Tennis: there will be a ladies' tournament at Corpus Christi Country Club and a men's tournament at the T-M Tennis Club.

Wednesday, 6-8:30 p.m., Ice Breaker Cocktail Party. Assembly/Banquet Room of the Convention Center, featuring open bar with light snacks.

Thursday, Corpus Christi Goes Country \& Western! Wear those western duds, if you choose, for dinner and dancing in the Assembly/Banquet Room of the Convention Center. Bar opens at 7 p.m., seated dinner begins at 7:30 p.m., and music by Ray Price is from 9 p.m. to $1 \mathrm{a} . \mathrm{m}$. Come enjoy great food and great musical entertainment by one of the all-time greats in the field of Country \& Western music.

\section{Ladies' Activities}

On Thursday, October 22, the ladies will have two choices: (1) a trip up the coast to Rockport, a thriving art center and resort community on the Gulf Coast, with enough time for shopping in the unique shops and art galleries; (2) an all-day trip to Old Mexico-you will walk across the border from Brownsville to Matamoros and enjoy browsing in the shops.

On Friday, October 23, there will be a champagne brunch at the Corpus Christi Country Club with an informal fashion show and a dramatic presentation.

\section{Field Trips}

Modern Depositional Environments of Sands in South Texas, Tuesday and Wednesday, October 20 and 21-A 2-day trip to Padre and Mustang Islands, Corpus Christi Bay, Laguna Madre, Nueces River, Baffin Bay, and the south Texas eolian system; participants will examine eolian, fluvial, deltaic, bay-lagoon, and barrier island environments with emphasis on deposition of sands. Leaders will be Gerald Shideler, John Russell, and Chuck Stelting.

Gulf Coast Uranium, Saturday and Sunday, October 24 and 25-A 2-day trip into the south Texas uranium mining area, with stops at open pit and in-situ leach uranium mining operations. The geology of uranium deposits and production technology will be examined. Leaders are Robert J. Finley and representatives of uranium operations visited on the trip.

Geology of Peregrina and Novillo Canyons, Ciudad Victoria, Mexico, Friday evening through Monday, October 23-26-A 4-day trip to Peregrina and Novillo Canyons in the Sierra Madre Oriental near Ciudad Victoria, Mexico, to examine geologic structures and Mesozoic, Paleozoic, and Precambrian stratigraphy; emphasis will be on outcrops of Jurassic and Cretaceous units which have subsurface Gulf Coast equivalents.

\section{GCAGS Abstracts}

AHR, WAYNE M., Texas A\&M Univ., College Station, TX Gilmer Limestone: Oolite Tidal Bars on Sabine Uplift

Studies of cores, cuttings, and sample logs have shown that the Cotton Valley Limestone, also known as the "Gilmer Limestone," consists of a linear belt of oolitic and pelletal grainstones and packstones along the margin of the Sabine uplift. This belt extends from Gilmer field in Upshur County southward at least as far as Overton field in Smith County. The oolite grainstone sequences with leached, "chalky" porosity are restricted to the north-south trend and are replaced by lime-muddy, nonporous rocks to the east and west.
The high percentage of ooids, the abundant festoon and tabular cross-beds in the grainstone belt, and the linear-shoal anatomy of the unit suggest that the Gilmer Limestone is an ancient analog of the tidal bars in the modern Bahamas. The Gilmer grainstones formed as a series of submarine bars which accumulated in the shallow, agitated water along the flanks of a peninsular shoal (the Sabine uplift). Because the rocks formed as a series of tidal bars, local variations in thickness and lithic character are along the trend.

The Gilmer Limestone reservoir exhibits "chalky" porosity that resulted from leaching during regressive cycles in the Cotton Valley. Oomoldic porosity and dolomite are rare to absent, and permeability is low because most of the voids are intragranular rather than intergranular. The leaching appears to have been most extensive along the tops of the thickest oolite shoals.

AHR, WAYNE M., Texas A\&M Univ., College Station, TX, and GREGORY J. PALKO, Arco Oil Co., Midland, TX

Depositional and Diagenetic Cycles in Smackover LimestoneSandstone Sequences, Lincoln Parish, Louisiana

The Jurassic upper Smackover Formation in Lincoln Parish, Louisiana, consists mainly of nonskeletal grainstones, argillaceous, anhydritic dolomitic mudstones to wackestones, and bioturbated to graded siliciclastics. Two shoaling-upward cycles, the "A and B limes" of local stratigraphers, were identified. These grainstone deposits accumulated as tidal bars on east-west trending paleo-highs ("salt structures") which parallel regional depositional strike. The salt ridges originated during middle Smackover deposition along the northern rim of the north Louisiana salt basin and produced a "slope-break" on the regional Smackover ramp.

Between the salt ridges in the study area is an inter-ridge trough or withdrawal basin. The strike-trending trough was filled episodically with mixtures of grain carbonates, sandstones, siltstones, and shales. The siliciclastics include finingupward litharenites and graded, alternating grainstonesandstone bedsets. The textural grading probably reflects strong but intermittent wave drift or storm surge currents that moved from east to west along the flanks of the salt highs. The finer grain rocks occur in the withdrawal basin center.

Diagenetic products observed in thin sections indicate that the Smackover carbonates were exposed to early marine, meteoric phreatic, and subsurface diagenesis. Marine diagenesis included micritization and isopachous aragonite rim cementation. Freshwater diagenesis included leaching of allochems and cements, and precipitation of blocky calcite rim and mosaic cements. Subsurface diagenesis included precipitation of pore-filling and replacement anhydrite, silicification, and stylolitization. The distribution of early diagenetic effects basically follows the trend of the salt ridges.

BARIA, LAWRENCE R., Tideway Energy Resources, Inc., Jackson, MS

Waveland Field, an Analyses of Facies, Diagenesis, and Hydrodynamics in Mooringsport Reservoirs

Although Waveland field was discovered in 1965, only in the last few years has development changed this once insignificant field into a 24,000 -acre $(9,600$ ha.) producing area flowing nearly 4 Bcf of gas per month. Part of the reason for the field's unusual growth rate is found in a host of reservoir disguises related to carbonate facies, diagenesis, and fracturing.

All of the field wells to date have penetrated a uniform sequence of back-reef and lagoonal deposits in the Mooringsport (lower Albian) producing interval. Miliolid and pellet 